\title{
EFFECT OF AGGRESSIVE BEHAVIOR OF THE SCHIZOPRENIC PATIENTS ON THE LEVEL OF STRESS OF MENTAL HEALTH NURSES AT SOUTH EAST SULAWESI MENTAL HOSPITAL
}

\author{
Baulija, Sukma Ayu, Habel Pandonggi \\ Masters Program in Public Health, School of Health Sciences Mandala Waluya, Kendari
}

\begin{abstract}
Background: The dispute of job stress among nurses is one of the core concerns in the field of psychiatric nursing. It was found that stress brought harmful impacts on both nurses' health and their ability to cope with job demands. The study aimed to examine the effects of aggressive behavior of the schizoprenic patients on the level of stress of mental health nurses at South East Sulawesi mental hospital.

Subjects and Method: This was a cross sectional study conducted at govermental psychiatric hospital South East Sulawesi Province. A total sample of 62 psychiatric nurses was selected for this study by simple random sampling. The dependent variable was level of stress. The independent variable was aggressive behavior of the schizoprenic patients. The data were colected by questionnaire. Strength of correlation was measured by Spearman correlation coefficient.

Results: Level of stress of mental health nurses was correlated with aggressive behavior of the schizoprenic patients $(\mathrm{r}=0.19 ; \mathrm{p}=0.010)$.

Conclusion: Level of stress of mental health nurses is correlated with aggressive behavior of the schizoprenic patients.
\end{abstract}

Keywords: aggressive behavior, schizoprenic patients, level of stress

\section{Correspondence:}

Baulija. Masters Program in Public Health, School of Health Sciences Mandala Waluya. Jl. A.H. Nasution No. G37, Kendari, South East Sulawesi. Email: baulija@gmail.com. Mobile: 081341610798. 